University of Michigan Law School

University of Michigan Law School Scholarship Repository

\title{
Multinational Firms and Tax Havens
}

\author{
Anna Gumpert \\ Ludwig-Maximilians-Universität München, anna.gumpert@econ.Imu.de \\ James R. Hines Jr. \\ University of Michigan Law School, jrhines@umich.edu \\ Monika Schnitzer \\ University of Munich, Department of Economics, schnitzer@econ.Imu.de
}

Available at: https://repository.law.umich.edu/articles/1832

Follow this and additional works at: https://repository.law.umich.edu/articles

Part of the Business Organizations Law Commons, Comparative and Foreign Law Commons, Economics Commons, and the Taxation-Transnational Commons

\section{Recommended Citation}

Hines, James R., Jr., co-author. "Multinational Firms and Tax Havens." A. Gumpert and M. Schnitzer, coauthors. The Rev. of Econ. and Stat. 98, no. 4 (2016): 713-27.

This Article is brought to you for free and open access by the Faculty Scholarship at University of Michigan Law School Scholarship Repository. It has been accepted for inclusion in Articles by an authorized administrator of University of Michigan Law School Scholarship Repository. For more information, please contact mlaw.repository@umich.edu. 


\title{
MULTINATIONAL FIRMS AND TAX HAVENS
}

\author{
Anna Gumpert, James R. Hines Jr., and Monika Schnitzer*
}

Abstract-Multinational firms with operations in high-tax countries can benefit the most from reallocating taxable income to tax havens, though this is sufficiently difficult and costly that only $20.4 \%$ of German multinational firms have any tax haven affiliates. Among German manufacturing firms, a 1 percentage point higher foreign tax rate is associated with a $2.3 \%$ greater likelihood of owning a tax haven affiliate. This is consistent with tax avoidance incentives and contrasts with earlier evidence for U.S. firms. The relationship is less strong for firms in service industries, possibly reflecting the difficulty of reallocating taxable service income.

\section{Introduction}

$\mathrm{T}$ AX havens are typically small, well-governed states that impose low or zero tax rates on foreign investors (Dharmapala \& Hines, 2009). Sophisticated tax avoidance strategies involving tax havens have received considerable attention in the media (Drucker, 2010; "Wake Up and Smell the Coffee," 2012; Lucas, Jopson, \& Houlder, 2012), and tax havens have repeatedly been the focus of national and international policy measures. To name a few examples, the OECD launched its Harmful Tax Competition project in 1996 to pressure tax havens to abolish harmful tax provisions and practices. France announced plans to introduce a $50 \%$ tax on income earned by French affiliates in tax havens in February 2010. The U.S. House Committee on Ways and Means held a background hearing on the transfer pricing practices of U.S. taxpayers, with an emphasis on income reallocation to offshore tax havens. The United Kingdom Parliament Committee of Public Accounts held widely publicized hearings in 2012 concerning the use of tax havens by foreign multinational firms operating in Britain. Partly as a consequence, the G-20 finance ministers in their February 2013 meeting pledged to take collective action to develop measures to address tax base erosion and profit shifting, tasking the OECD with recommending policies that could be

Received for publication August 28, 2013. Revision accepted for publication November 23, 2015. Editor: Asim I. Khwaja.

*Gumpert: LMU Munich and CESifo; Hines: University of Michigan and NBER; Schnitzer: LMU Munich, CESifo, and CEPR.

This paper was partly written during visits of the first and third authors to the research center of the Deutsche Bundesbank. The hospitality of the Bundesbank, the constructive support of the staff, as well as access to its Microdatabase Direct investment (MiDi) are gratefully acknowledged. The project has benefited from financial support through the Deutsche Forschungsgemeinschaft (German Science Foundation) under SFB-Transregio 15 and GRK 801. We thank Johannes Becker, Thiess Buettner, Ronald Davies, Dhammika Dharmapala, Rachel Griffith, Andreas Haufler, Shafik Hebous, Niels Johannesen, Iris Kesternich, Nadine Riedel, Erik Röder, Richard Schmidtke, Emmanuelle Taugourdeau, Till von Wachter, and Martin Watzinger, as well as conference participants at the the CESifo Conference on Corporate Taxes and Corporate Governance, the Tax Havens Conference at the Max-Planck Institute Munich, the 10th Journées Louis-André Gérard-Varet, the 67th IIPF Congress, the meeting of the SFBTransregio 15, the first CBT Doctoral Meeting, the 9th Bundesbank MiDi Workshop, and the Royal Economic Society 2012 Annual Conference for helpful comments. Asim Khwaja and three anonymous referees offered many constructive suggestions that are incorporated in this paper.

A supplemental appendix is available online at http://www.mitpress journals.org/doi/suppl/10.1162/REST_a_00591. enacted by national governments, which resulted in OECD recommendations to the G20 finance ministers in October 2015.

What drives the policy interest is the concern that tax havens are widely used to avoid tax obligations, particularly those due to high-tax countries. This concern is consistent with at least some of the evidence: the U.S. Congress Joint Committee on Taxation (2010) report identifies specific methods by which U.S. firms use transactions with tax haven affiliates to avoid tax obligations, and Desai, Foley, and Hines (2006) offer evidence that ownership of a regional tax haven affiliate is associated with reduced foreign tax payments. It is clear, however, that corporations cannot use tax haven operations to avoid all taxes easily and comprehensively, as reflected in persistent significant corporate tax collections by high-tax countries. Furthermore, Desai et al. (2006) offers evidence that in 1999, just 59\% of U.S. multinationals with significant foreign operations had any tax haven affiliates. This suggests that substantial tax avoidance opportunities through the use of tax haven operations are selectively available only to certain firms, industries, or activities, though the available evidence describes only U.S. firms.

The purpose of this paper is to identify factors associated with demand by German multinational firms for tax haven operations. German firms are major foreign investors, so their use of tax havens to avoid taxes is potentially quite important; furthermore, evidence of their tax haven use is a valuable complement to existing studies of the behavior of U.S. firms. The data indicate that among manufacturing firms, those that are larger and more productive are the most likely to have tax haven affiliates. Notably, manufacturing firms whose nonhaven foreign operations are located in hightax countries are more likely than others to have tax haven affiliates. These patterns are consistent with a simple model of profit reallocation, in which some firms find that the benefits of being able to reallocate taxable income from high-tax jurisdictions exceeds the cost of establishing tax haven affiliates, whereas other multinational firms, with fewer profits to reallocate or fewer taxes to save, do not. Among firms in service industries, tax haven use is less closely associated with high foreign tax rates, quite possibly reflecting the more limited scope for taxable income reallocation among firms in service industries.

It is noteworthy that relatively few German firms use tax havens. In the sample of all German multinational firms from 2002 to 2008 , only $20.4 \%$ have tax haven affiliates. This is considerably smaller than the fraction of U.S. firms using tax havens and is smaller still when the sample is limited to German manufacturing firms. This pattern implies that cost-effective tax avoidance opportunities through the use of tax havens may be quite limited for German firms and 
that the U.S. evidence of more widespread, though nonetheless still limited, tax haven use may be atypical on the high side. It is particularly striking that German firms would be less likely to use tax havens than are U.S. firms, given that the U.S. worldwide tax system does more than does the German territorial tax system to limit the benefits of reallocating taxable income from high-tax countries to low-tax countries. Many firms could benefit from reallocating taxable income to affiliates located in nonhaven countries that have moderately low tax rates, though the most aggressive and successful tax avoidance is commonly thought to involve tax havens. As a result, this study focuses on tax haven operations.

Much of the available evidence on the determinants of tax haven use by multinational firms comes from studies of U.S. firms, whose tax treatment differs from those of firms based in almost any other major capital-exporting country. Income earned by foreign subsidiaries of U.S. firms is subject to U.S. taxation when repatriated, at which time U.S. taxpayers can claim credits for income taxes paid to foreign governments. This system reduces the incentive to use tax haven operations to avoid foreign taxes, since foreign tax reductions entail fewer foreign tax credits, and therefore greater U.S. tax liability, when income is ultimately repatriated. The system does, however, encourage the use of tax havens to the extent that they facilitate deferral of home country taxes, such as by serving as coordination centers to direct foreign profits to new foreign investments.

Germany taxes only $5 \%$ of the active foreign business profits of its resident corporations. In this respect, the German tax system is similar to those in the United Kingdom, Japan, France, Canada, Italy, and most OECD countries, particularly the major capital exporters. German firms consequently have strong incentives to avoid foreign taxes, since foreign tax savings do not entail greater home country taxes when income is repatriated. Furthermore, German firms do not have incentives to structure their foreign operations in ways that avoid repatriating income. Therefore, the tax incentives for German firms to establish tax haven affiliates are likely to differ from those of U.S. firms and bear strong similarities to those of other G-7 and OECD firms. To gauge the impact of foreign taxation on tax haven investment by German firms, the paper estimates a linear probability model of tax haven investment using the sizes of a firm's foreign and domestic activities, and the firm's R\&D intensity, as additional control variables. The empirical strategy uses the panel nature of the data to account for the fact that the tax rates a firm faces at its foreign locations may be endogenous to its decision to invest in a tax haven: specifically, the estimation relies on statutory foreign tax changes subsequent to a base year. The estimates indicate that a 1 percentage point higher foreign tax rate is associated with a $2.3 \%$ greater likelihood of having a tax haven affiliate, presumably reflecting the greater benefit of reallocating taxable income from high-tax countries.
This paper is related to two strands of the literature: one on the use of tax havens by multinational firms and the other on profit reallocation. Harris et al. (1993) analyze a fiveyear panel of 200 large U.S. manufacturing firms and find that U.S. tax liabilities of U.S. firms holding affiliates in Ireland or one of the four low-tax "dragon" Asian countries are systematically lower than those of U.S. firms without such activities. Hines and Rice (1994) analyze a cross-section of country-level data on the activities of U.S. multinational firms, finding that U.S. multinationals report disproportionate shares of profits in tax havens, which suggests that income may be reallocated for tax purposes. Grubert and Slemrod (1998) use a cross-section of data and estimate a joint model of the investment and profit-shifting decision of U.S. multinationals in Puerto Rico, which, due to its special status, can serve as a tax haven for U.S. firms. They find that firms with intangible assets are more likely than others to invest in Puerto Rico.

Desai et al. (2006), who are closest to our analysis, use an affiliate-level data set on U.S. multinationals' foreign activities in four years between 1982 and 1999. They estimate a logit model of tax haven investment given parent characteristics and take into account the endogeneity of the foreign nonhaven tax rate due to simultaneity of a parent's location decisions. They find a negative effect of the average foreign nonhaven tax rate on the probability of investing in a tax haven, interpreting their finding as evidence of the impact of incentives induced by the ability to defer home country taxation of unrepatriated foreign profits. Thus, it is particularly interesting to compare the U.S. evidence with the tax haven investment behavior of firms that are subject to a tax exemption regime, as German firms are, which have clear incentives to use tax haven operations to reallocate taxable income.

There is a vast literature on international profit shifting, so for brevity, it is helpful to review just recent examples of different strands of the literature. That taxes influence reported profits has been documented by Huizinga and Laeven (2008), among others. They use a cross-section of European multinational enterprises (MNEs) and find evidence for substantial profit shifting between different countries in Europe, which fits international profit-shifting incentives that arise from tax differences between the parent and host country and among different affiliate locations. Weichenrieder (2009) analyzes a panel data set of German inbound and outbound FDI and identifies empirical patterns that are consistent with profit shifting in both cases.

With respect to different profit-shifting strategies, Clausing $(2001,2003,2006)$ provides empirical evidence that taxes exert a substantial impact on transfer prices and intrafirm trade flows of U.S. firms, while Vicard (2014) provides complementary evidence for French firms. Dischinger and Riedel (2011) offer evidence from a panel data set of European firms that MNEs prefer locating intangible assets in low-tax locations, arguably doing so because they are able to choose favorable transfer prices for intangible 
assets. Karkinsky and Riedel (2012) report similar findings with respect to patent location within MNEs. Egger et al. (2010) compare the debt-to-asset ratios of domestically and foreign-owned European firms and identify a gap in the ratios systematically related to corporate tax rates. Buettner et al. (2009) provide further evidence on tax-motivated choice of capital structure using a panel data set of German MNEs. Using the same data, Buettner and Wamser (2013) analyze the use of intrafirm loans for profit shifting, but find that they have rather small tax revenue effects. Weichenrieder and Mintz (2010), as well as Wamser (2011), show, using data on German MNEs, that firms tactically locate their direct and indirect affiliates and strategically use ownership chains in a way that facilitates tax avoidance. Many of these studies, as well as others (e.g., Desai et al., 2009) analyzing the behavior of multinational firms, confine their analysis to manufacturing firms. This is done both due to the importance of manufacturing and in an effort to control for firm heterogeneity. As a result, differences in profit-shifting opportunities between firms in different industries have been much less extensively studied.

\section{Incentives to Establish Tax Haven Operations}

In this section we lay out a stylized theoretical framework to describe the incentives of a multinational firm to invest in a tax haven and derive the main empirical prediction we test.

Consider a multinational firm that can invest in a range of countries $i=0, \ldots, n$, including a tax haven, which is denoted as country 0 . Starting a foreign affiliate involves fixed setup cost $c_{i}$. Let $\rho_{i}$ denote before-tax profits earned in country $i$ by the affiliate once it is installed. Reported profits are taxed at rate $\tau_{i}$ in country $i$. Without loss of generality, we assume that $\tau_{0}=0$; that is, there is no taxation in the tax haven.

Firms can reallocate an amount $\psi_{i}$ of their actual profits in country $i$ to a country that taxes reported profits at a lower tax rate, most notably to the tax haven country-for example, by adjusting their transfer prices. This is possible only at some cost. Firms may need to set up additional facilities to make transfer prices seem plausible, inefficient relocation of production and intrafirm trade may be needed to arrange income reallocation, and transaction costs, like legal expenses, are incurred. We assume that income reallocation gets increasingly expensive as the amount reallocated increases relative to income earned in country $i$. Following Hines and Rice (1994), these income reallocation costs are assumed to be $(a / 2)\left(\psi_{i}{ }^{2} / \rho_{i}\right) .{ }^{1}$ Parameter $a$ captures how much the cost of income reallocation increases with the amount reallocated. Note that $a$ is a firm-specific parameter because income reallocation costs may vary with firm-specific characteristics such as ownership of intangible assets. In the following, we

\footnotetext{
${ }^{1}$ For simplicity, we assume that the costs of reallocating income to a tax haven and another nonhaven country are equal. This assumption does not affect the main intuition of the model but renders notation far more tractable.
}

assume that the income reallocation cost are incurred in the country from which income is shifted, though the model's implications are quite similar if these costs are incurred in the country to which the income is transferred. ${ }^{2}$ The reported profit in country $i, \pi_{i}$, after fixed cost $c_{i}$ is sunk, is thus

$$
\pi_{i}=\rho_{i}-\psi_{i}-\frac{a}{2} \frac{\psi_{i}^{2}}{\rho_{i}} .
$$

Consider now the option of setting up an affiliate in a tax haven at cost $c_{0}$. To save on notation, we set $\rho_{0}=0$ and let $c_{0}$ capture the net cost of investing in a tax haven, after deducting any profits that arise genuinely in this country. Note that due to antideferral regulations, firms may have to incur considerable fixed costs to set up a tax haven affiliate that may be used for profit reallocation purposes. ${ }^{3}$ For $c_{0}<0$, the multinational has an interest in investing in a tax haven country and does so, independent of investments in other countries. This interest could arise from plans to reallocate income from the home country. However, since our data set contains information on parent firms from only one home country, it is not possible to gauge the impact of this tax incentive empirically. Thus, we focus on multinationals that invest in nonhaven countries as well.

To evaluate the incentive to invest in a tax haven, consider first the situation of a multinational with a tax haven affiliate. The firm chooses in which other countries to locate affiliates and how much of their profits to reallocate to the tax haven. Thus, the investor's maximization problem, given that it has a tax haven affiliate, is

$$
\max _{d_{i}, \psi_{i}} \sum_{i=1}^{n} d_{i}\left[\psi_{i}+\left(1-\tau_{i}\right)\left(\rho_{i}-\psi_{i}-\frac{a}{2} \frac{\psi_{i}^{2}}{\rho_{i}}\right)-c_{i}\right],
$$

with $d_{i} \in\{0,1\}$, s.t.

$$
\rho_{i}-\psi_{i}-\frac{a}{2} \frac{\psi_{i}^{2}}{\rho_{i}} \geq 0 \forall i=1, \ldots, n .
$$

The following lemma describes the solution to this maximization problem. For ease of presentation, we restrict consideration to parameter cases such that an interior solution is obtained. ${ }^{4}$

Lemma 1. Suppose the investor has a tax haven affiliate. Then the optimal amount of profit shifting is

$$
\psi_{i}^{* t h}=\frac{\tau_{i} \rho_{i}}{a\left(1-\tau_{i}\right)} .
$$

${ }^{2}$ This and other extensions to the model, along with tables reporting supplementary regressions, are presented in supplementary material available at http://www.mitpressjournals.org/doi/suppl/10.1162/REST_a_00591.

${ }^{3}$ For details on the taxation of foreign profits of German multinationals and the antideferral regulations, refer to the online supplementary material.

${ }^{4}$ This is the case if $\tau_{i} \leq 1-\sqrt{\frac{1}{2 a+1}}$, which is trivially fulfilled for $a$ sufficiently large. 
Let countries be numbered such that country $i=1$ yields the highest after-tax profit, including the fixed cost of setting up the affiliate, and country $i=n$ yields the lowest profit. Then the multinational chooses $d_{i}=1$ for all countries $i=$ $1, \ldots, \tilde{n}$, where $\tilde{n}$ is determined by the condition

$$
\begin{aligned}
& \psi_{\tilde{n}}+\left(1-\tau_{\tilde{n}}\right)\left(\rho_{\tilde{n}}-\psi_{\tilde{n}}-\frac{a}{2} \frac{\psi_{\tilde{n}}^{2}}{\rho_{\tilde{n}}}\right)-c_{\tilde{n}} \geq 0> \\
& \psi_{\tilde{n}+1}+\left(1-\tau_{\tilde{n}+1}\right)\left(\rho_{\tilde{n}+1}-\psi_{\tilde{n}+1}-\frac{a}{2} \frac{\psi_{\tilde{n}+1}^{2}}{\rho_{\tilde{n}+1}}\right)-c_{\tilde{n}+1} .
\end{aligned}
$$

Proof. See the online supplementary material.

Consider now the multinational's situation if it has no tax haven affiliate. In this case, profit shifting has to be directed to the country charging the lowest tax rate among those in which the multinational holds an affiliate. ${ }^{5}$ Let $\underline{\tau}$ denote the minimum of all tax rates charged in countries in which the multinational invests. In the supplementary material, we derive the optimal amount of profit shifting $\psi_{i}^{* \text { nth }}$ and describe the optimal number of countries $\hat{n}$ in which to set up a foreign affiliate. It is straightforward to show that $\tilde{n} \geq \hat{n}$, since the profits realized from each country are potentially larger if it is possible to reduce taxes by reallocating income to a tax haven.

To determine the incentive to set up a tax haven investment, let

$$
\Pi_{i}^{\text {th }}=\psi_{i}^{* \text { th }}+\left(1-\tau_{i}\right)\left[\rho_{i}-\psi_{i}^{* t h}-\frac{a}{2} \frac{\psi_{i}^{* h^{2}}}{\rho_{i}}\right]-c_{i}
$$

denote the maximal after-tax profit generated in nonhaven country $i$ when the company invests in a tax haven, and similarly, let

$$
\begin{aligned}
\Pi_{i}^{n \text {th }}= & (1-\underline{\tau}) \psi_{i}^{* \text { th }} \\
& +\left(1-\tau_{i}\right)\left[\rho_{i}-\psi_{i}^{* n t h}-\frac{a}{2} \frac{\psi_{i}^{* n t h^{2}}}{\rho_{i}}\right]-c_{i}
\end{aligned}
$$

denote the maximal after-tax profit generated in a nonhaven country $i$ when the company does not invest in a tax haven but can shift income to a nonhaven country with tax rate $\tau$. Let $I n c_{t h}$ denote the net benefit ("Incentive") from investing in a tax haven at a setup cost of $c_{0}$. Then investing in a tax haven is optimal if and only if

$$
I n c_{t h} \equiv \sum_{i=1}^{\hat{n}}\left[\Pi_{i}^{t h}-\Pi_{i}^{n t h}\right]+\sum_{i=\hat{n}+1}^{\tilde{n}} \Pi_{i}^{t h}-c_{0}>0 .
$$

The main focus of our paper is to determine the impact of tax rates on the incentive to set up a tax haven. Proposition 1 describes how a change in tax rates in countries in

\footnotetext{
${ }^{5}$ We assume for simplicity that the multinational shifts profits to one country only. Giving up this assumption would yield computation far more complicated but would not affect our results qualitatively.
}

which the multinational is active independent of a tax haven investment, that is, $i=1, \ldots, \hat{n}$, affects the incentive to set up a tax haven.

Proposition 1. The larger the tax rate in countries in which the multinational is active independent of a tax haven investment, the larger is the incentive to establish a tax haven affiliate:

$$
\begin{aligned}
\frac{d I n c_{t h}}{d \tau_{i}}= & \frac{d\left(\Pi_{i}^{t h}-\Pi_{i}^{n t h}\right)}{d \tau_{i}}=\left(\psi_{i}^{* t h}-\psi_{i}^{* n t h}\right) \\
& +\left[\frac{a}{2} \frac{\psi_{i}^{* t h^{2}}}{\rho_{i}}-\frac{a}{2} \frac{\psi_{i}^{* n t h^{2}}}{\rho_{i}}\right]>0 \forall i=1, \ldots, \hat{n} .
\end{aligned}
$$

Proof. See the online supplementary material.

Intuitively, when a company has a tax haven affiliate, it avoids profits in nonhaven countries more than when it does not. Thus, the larger are the tax rates in the nonhaven countries, the larger is the multinational's incentive to avoid taxes. This is the main prediction of the model tested in section VI.

For the interpretation of our empirical results, it is instructive to evaluate also the effect of tax changes in countries in which the multinational is active only in case of a tax haven investment (see the supplementary material for a derivation):

$$
\begin{gathered}
\frac{d \operatorname{Inc} c_{t h}}{d \tau_{i}}=\frac{d \Pi_{i}^{t h}}{d \tau_{i}}=-\left[\rho_{i}-\psi_{i}^{* t h}-\frac{a}{2} \frac{\psi_{i}^{* t h^{2}}}{\rho_{i}}\right]<0 \\
\forall i=\hat{n}+1, \ldots, \tilde{n} .
\end{gathered}
$$

This result has the notable implication that a multinational may in fact be tempted to invest in a tax haven following a tax reduction in a country in which it has not been present so far. This prima facie counterintuitive situation can arise if this tax reduction makes an investment in this country attractive and hence adds to the potential base for profit shifting. It remains the case that, conditional on foreign pretax income, higher foreign tax rates increase a firm's demand for tax haven operations, but foreign tax changes influence the production of pretax income in a way that can produce an unconditional association of higher foreign tax rates with reduced tax haven demand.

\section{Taking Theory to the Data}

In this section we discuss some conceptual issues to be considered in order to test the prediction laid out in proposition 1 and interpret the empirical results in sections VI and VII. First, the multinational can be engaged in several countries, and hence the tax rates of all these countries matter, but potentially to a different extent. Thus, individual tax rates have to be weighted. Second, we are not able to observe actual profits, only reported after-tax profits. Third, the foreign tax rates observed are potentially affected by tax 
haven investments, so the endogeneity needs to be addressed. Fourth, firms may exhibit heterogeneous costs of profit shifting and hence may differ in their sensitivity to tax rate changes.

\section{A. Weighting Individual Tax Rate Changes}

When attempting to identify the effect of foreign tax rates on the tax haven decision, we need to take into account that the multinational is potentially engaged in several countries and therefore the tax rates of all these countries matter. As equation (11) shows, they do so to a different extent, however, depending on the profitability of the individual affiliates (see the supplementary material):

$$
\frac{d^{2} I n c_{t h}}{d \tau_{i} d \rho_{i}}=\frac{\underline{\tau}(2-\underline{\tau})}{2 a\left(1-\tau_{i}\right)^{2}}>0 \forall i=1, \ldots, \hat{n} ;
$$

that is, higher profits increase the effect of the foreign tax rate. We capture this by investigating the impact of the average nonhaven tax rate, where all the foreign tax rates are weighted by the profitability of the individual affiliate. If the multinational has not invested in a tax haven, this average foreign tax rate is determined by the tax rates in countries $i=1, \ldots, \hat{n}$ and is given by

$$
\frac{\sum_{i=1}^{\hat{n}} \tau_{i} \rho_{i}}{\sum_{i=1}^{\hat{n}} \rho_{i}} \text {. }
$$

\section{B. Unobservability of Actual Profits}

In our empirical analysis, we encounter the difficulty that we are not able to observe the actual profits $\rho_{i}$ in country $i$, only reported after-tax profits $\left(1-\tau_{i}\right) \pi_{i}$. These reported profits are distorted due to taxation and income reallocation. In case of a tax haven investment, they are given by

$$
\begin{aligned}
\left(1-\tau_{i}\right) \pi_{i} & =\left(1-\tau_{i}\right)\left(\rho_{i}-\psi_{i}-\frac{a}{2} \frac{\psi_{i}{ }^{2}}{\rho_{i}}\right) \\
& =\left(1-\tau_{i}\right)\left[1-\frac{\tau_{i}\left(2-\tau_{i}\right)}{2 a\left(1-\tau_{i}\right)^{2}}\right] \rho_{i} .
\end{aligned}
$$

Inspection shows that this distortion rises with the country's tax rate $\tau_{i}$. Thus, we require appropriate proxies to capture the effect of an affiliate's profitability on the decision to invest in a tax haven. We will proxy the affiliate's profitability by the number of employees, as discussed in more detail below.

\section{Endogeneity of Observed Tax Rates to Tax Haven Investments}

Furthermore, we need to account for the fact that the average foreign tax rate we observe is potentially affected by the very fact of whether the multinational holds a tax haven affiliate. The tax haven investment may make it profitable to invest in foreign countries $i=\hat{n}+1, \ldots, \tilde{n}$, that would not have been attractive destinations for investments without the income reallocation opportunities created by the tax haven investment. Consider a change in tax rates $\Delta_{i} \geq 0$ in countries $i=1, \ldots, \tilde{n}$ such that the investor chooses to invest in a tax haven after this change in tax rates but would not do so before. According to equations (9) and (10), both an increase in the tax rates at locations $i=1, \ldots, \hat{n}$, where the multinational already holds an affiliate, and a decrease in the tax rates at locations $i=\hat{n}+1, \ldots, \tilde{n}$, which become attractive only after tax haven investment, could render tax haven investment optimal. The average nonhaven tax rate for the investor changes from the status quo described in equation (12) to the new average nonhaven tax rate:

$$
\frac{\sum_{i=1}^{\tilde{n}}\left(\tau_{i}+\Delta_{i}\right) \rho_{i}}{\sum_{i=1}^{\tilde{n}} \rho_{i}}
$$

Taking the difference between equations (14) and (12) yields the observed change in the nonhaven average tax rate, which can be rewritten as

$$
\frac{\sum_{i=1}^{\hat{n}} \Delta_{i} \rho_{i}}{\sum_{i=1}^{\tilde{n}} \rho_{i}}+\frac{\sum_{i=\hat{n}+1}^{\tilde{n}} \rho_{i}\left(\frac{\sum_{i=\hat{n}+1}^{\tilde{n}}\left(\tau_{i} \rho_{i}+\Delta_{i} \rho_{i}\right)}{\sum_{i=\hat{n}+1}^{\tilde{n}} \rho_{i}}-\frac{\sum_{i=1}^{\hat{n}} \tau_{i} \rho_{i}}{\sum_{i=1}^{\hat{n}} \rho_{i}}\right)}{\sum_{i=1}^{\tilde{n}} \rho_{i}} .
$$

In our empirical analysis, we are interested in identifying the effect of exogenous changes in tax rates in countries $i=1, \ldots, \hat{n}$, that is, countries in which the multinational would invest even without a tax haven affiliate. This exogenous change in tax rates is captured by the first term. As shown in equation (9), investing in a tax haven is positively influenced by an increase in the tax rates of the countries in which the multinational already holds affiliates. Thus, when estimating the impact of foreign tax rates, higher tax rates in countries in which a multinational firm would invest under any circumstances should stimulate greater demand for tax haven affiliates.

The second term captures the change in the observed nonhaven tax rate that is due to the endogeneity of the multinational's investment decision. Evaluating the numerator of the second term, we find that the observed change in the average nonhaven tax rate exceeds the change of interest if the new affiliates the multinational opens due to the tax haven investment are located in countries that exhibit on average higher tax rates than the previous average tax rate, and the converse.

This has important implications for the interpretation of the causal effects of tax changes. In particular, OLS results overestimate the true effects, as captured by the IV estimates, if the tax rates at the firm's new locations increase the firm's average foreign nonhaven tax rate, and underestimate the true effects if the tax rates faced at the new locations are lower than the previous average foreign nonhaven tax rate.

Consequently, there are several reasons that simple correlations of foreign nonhaven tax rates with tax haven affiliate 
ownership might not reflect the direct effect of higher foreign tax rates on tax haven demand. The first, as noted in equation (10), is that lower foreign tax rates may encourage firms to earn greater taxable foreign income, which directly increases their demand for tax haven operations. The second, as reflected in the second term of equation (15), is that ownership of a tax haven affiliate changes the pattern of nonhaven foreign investment, resulting in higher or lower measured average foreign nonhaven tax rates. A third reason, not captured by this model, is that firms with investments in tax havens may generally invest in other low-tax countries in order to reallocate some of their income to countries with tax rates not quite as low as those offered by tax havens. These considerations suggest that OLS estimates of the effect of nonhaven foreign tax rates on demand for tax haven affiliates may understate the true effect. The empirical work presented in section VI accounts for the potential endogeneity of the observed tax rate using an instrumentation strategy based on the locations of foreign nonhaven affiliates at the start of the sample period and restricts attention to changes in observed tax rates for these locations only.

\section{Heterogeneous Cost of Profit Shifting}

Our empirical strategy also needs to take into account that firms may differ with respect to their cost of reallocating profits between countries. As equation (16) shows, the more difficult profit shifting is for the multinational, the less sensitive will be its reaction to foreign tax rate changes (see the supplementary material):

$$
\frac{d^{2} I n c_{t h}}{d \tau_{i} d a}=-\frac{\rho_{i} \underline{\tau}(2-\underline{\tau})}{2 a^{2}\left(1-\tau_{i}\right)^{2}}<0 \forall i=1, \ldots, \hat{n} .
$$

Average foreign tax rates and values of the shifting cost parameter are likely to differ among firms and may vary systematically among industries. Industries may differ in average values of the shifting cost parameter $a$, reflecting differences in the importance of intangible assets and other business features that facilitate profit reallocation; industries may also differ in the extent to which $a$ varies among firms in the industry. Differentiating equation (16) with respect to $a$ indicates that

$$
\frac{d^{3} I n c_{t h}}{d \tau_{i} d^{2} a}=\frac{\rho_{i} \underline{\tau}(2-\underline{\tau})}{a^{3}\left(1-\tau_{i}\right)^{2}}>0 .
$$

Since the expression in equation (17) is positive, it follows that the effect of $a$ on $\frac{d \operatorname{lnc}}{d \tau_{i}}$ is nonlinear and, more specifically, that a mean-preserving spread in the distribution of $a$ produces a greater average value of $\frac{d I n c}{d \tau_{i}}$. Consequently, industries in which firms have very different costs of profit reallocation should be expected to display greater average sensitivity of tax haven demand to nonhaven tax rates than do other industries, although average costs of profit reallocation do not differ. We use firm-fixed effects in the baseline econometric analysis to control for differences in marginal costs of income reallocation and distinguish firms by industrial sectors to proxy for cost differences that vary with industry.

\section{Data and Descriptive Statistics}

Our analysis is based on the Microdatabase Direct investment (MiDi) provided by the Bundesbank, the German central bank. We use the information on outward foreign direct investment by German companies. The database consists of a panel of yearly information on the foreign affiliates of German firms for the period from 1996 until 2008. By the German Foreign Trade and Payment Regulation (Aussenwirtschaftsverordnung), any resident who holds shares or voting rights of at least $10 \%$ in a company with a balance sheet total of more than 3 million euros is obliged to report information on the financial characteristics of these affiliates to the Bundesbank (Lipponer, 2009). ${ }^{6}$ The same information has to be provided on branches or permanent establishments abroad if their operating assets exceed 3 million euro. The comprehensiveness of these data suggests that they can be used to draw a very reliable picture of the foreign investment of German companies.

The MiDi information on parent companies starts in 2002, so the analysis is restricted to 2002 to 2008 in order to avoid the effects of the crash of 2008 and its aftermath. ${ }^{7}$ During the 2002-2008 period, the MiDi contains 173,312 affiliateyear observations. Some affiliates are reported several times, because multiple investors hold participating interests in them. We focus our analysis on directly held foreign affiliates and thus abstract from more complex incentive structures that may exist in multilevel holding chains. ${ }^{8}$ This limits the analysis to 117,585 affiliate-year observations.

For consistency across parents, we delete 218 observations for which the degree of participation of the parent is smaller than the reporting requirement of $10 \%$. In addition, we drop observations on parents in a number of sectors, including government institutions and private households. We drop observations on parents in the financial sector, because they are subject to special balancing requirements. We delete the sectors housing enterprises and other real estate activities, as they report neither sales nor employees, which we will use as the size measure in our analysis. Similarly, we drop the sector holding companies as reported sales and employees are very often zero, even though these companies are

\footnotetext{
${ }^{6}$ The reporting thresholds have changed several times in the past. We refer only to the reporting threshold as of 2002 that is relevant to us.

${ }^{7}$ Prior to 2002 Germany taxed corporations using a split-rate system that imposed a lower rate of tax on profits distributed to shareholders as dividends and taxed dividends using an imputation system that granted credits to shareholders for taxes paid by corporations on their domestic (but not foreign) profits. This dividend imputation system may have reduced incentives to reallocate taxable income from Germany to foreign tax havens but was abolished in 2001 .

${ }^{8}$ For an in-depth discussion of the complex determinants of ownership chains, see Weichenrieder and Mintz (2010).
} 
Table 1.-Choice of Tax Havens, by Sectoral Group

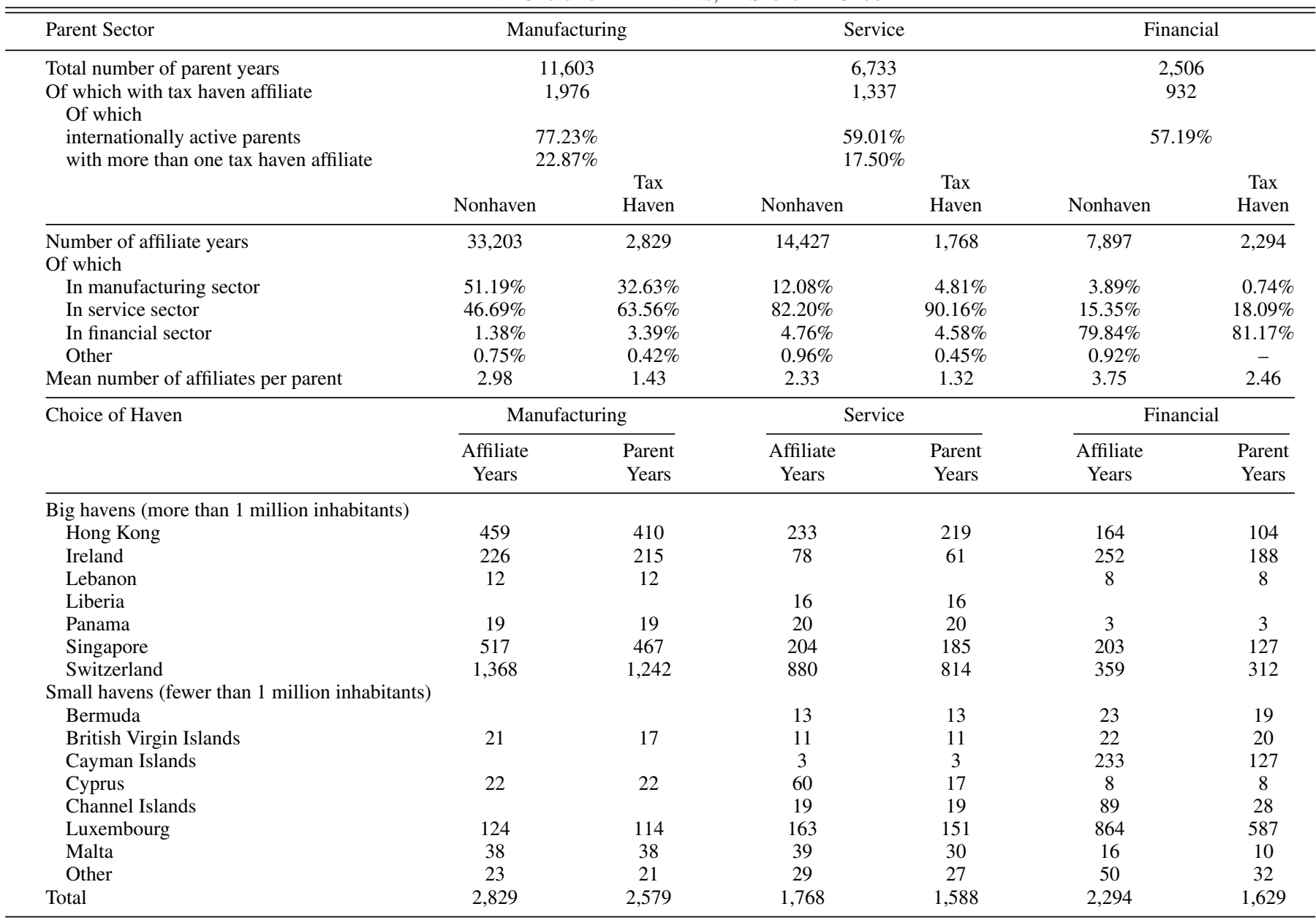

Empty cells denote tax havens where fewer than three affiliate-years or parent-years are observed, so the exact number of investments must not be reported for confidentiality reasons. Manufacturing firms: firms classified NACE 1500-3700; service firms: firms classified NACE 5000-9300, with the sample restrictions already noted; financial firms: firms classified NACE 6500-7000. If a parent invests in several tax havens, it is counted multiple times (once per tax haven).

not small. ${ }^{9}$ We later remove this restriction as a robustness check and find that our results are unaffected.

We finally obtain a sample of 54,367 affiliate-year observations that correspond to 19,165 parent-year observations. The observations are distributed evenly across years, with a minimum of 2,639 observations and a maximum of 2,875 observations.

We augment the MiDi with information on statutory tax rates mainly from the International Bureau of Fiscal Documentation (2002-2006, 2007-2009) and information on GDP from the International Monetary Fund (IMF). We use the definition of tax havens derived by Hines and Rice (1994), which is widely accepted in the literature and was only recently used by Dharmapala and Hines (2009). ${ }^{10}$ Alternatively, we could have used the definition propagated by

${ }^{9}$ We also delete 331 affiliate-year observations for parents that are not classified holdings, but are de facto holdings after consultations with the staff of the Bundesbank.

${ }^{10}$ Switzerland is included among the tax havens on this list and is commonly considered one of the world's most important tax havens from the standpoint of corporate tax planning. Of the six examples of sophisticated international tax avoidance by U.S. firms analyzed in detail by the Joint Committee on Taxation (2010), three rely on the use of Swiss affiliates. the OECD (2000). We chose Hines and Rice's (1994) tax haven definition to derive results that are comparable to the literature, in particular the study by Desai, Foley, and Hines (2006). Further, no OECD member countries appear on the OECD's tax haven list, which thereby omits a number of tax havens popular with German firms, such as Switzerland.

Table 1 presents descriptive evidence on the use of tax havens by sectoral group. For comparative purposes, information on financial firms is provided in addition to information on firms in the manufacturing and service sector, which we analyze in later sections.

On average, a tax haven affiliate is held in $20.4 \%$ of parentyears (17.9\% excluding financial companies). This figure seems low by international standards: Desai et al. (2006) report that tax haven investment is observed for $59 \%$ of U.S. multinational parent companies in 1999.11 This difference

We are unable to distinguish investment in Monaco and Saint Martin from investment in France, so these tax havens are neglected in our analysis.

${ }^{11}$ Desai, Foley, and Hines (2004) use the same data as Desai et al. (2006) and report that U.S. parents own between 7.5 and 7.8 affiliates on average in the years 1982, 1989, and 1994. Parents in our sample average only 2.8 foreign affiliates (4.0 if indirectly held affiliates are included). 
reflects, in part, the inclusiveness of the MiDi data, in that the size thresholds for reporting are much lower than in the U.S. data analyzed by Desai et al. (2006), resulting in a higher proportion of small firms and those with relatively small foreign operations.

The proportion of firms owning tax haven affiliates is higher for service firms (19.9\%) than for manufacturing firms (17.0\%), and a larger proportion of service firms own a tax haven affiliate but are not internationally active in nonhaven countries. About a fifth of both manufacturing and service firms that are present in tax havens own more than one tax haven affiliate, and the mean number of tax haven affiliates is also approximately equal. In contrast, $37.2 \%$ of financial firms hold affiliates in tax havens, and they own on average twice as many tax haven affiliates as do manufacturing and service firms.

The share of affiliates in tax havens that are in the service sector is disproportionately high. For manufacturing firms, the share of service affiliates in tax havens is about 17 percentage points higher than their overall share of affiliates in the service sector, and for service firms, it is 8 percentage points higher. Also for financial companies, investment in service affiliates is more common in tax havens than in nonhaven countries.

The lower panel of table 1 reports the number of affiliateyear and parent-year observations by tax haven and sectoral group of the parent firm. It shows that the preferred tax haven destination varies by sectoral group. Manufacturing firms clearly prefer the big tax havens. More than $90 \%$ of observations are accumulated there-about $48 \%$ in Switzerland alone. The island tax havens, in particular Bermuda, the Cayman Islands, and the Channel Islands, are very rare investment destinations. Switzerland is similarly popular among service firms; about half of their tax haven affiliates are located there. Service firms more extensively use the small havens, where almost a fifth of tax haven affiliates are located, most prominently $9 \%$ in Luxembourg. For financial companies, Luxembourg is distinctly the most popular destination, with $38 \%$ of affiliate-year observations in tax havens. The Cayman Islands are their fourth most important tax haven destination: $10 \%$ of affiliate-year observations in tax havens are located there. Evidently the attractiveness of tax havens strongly depends on sector characteristics.

Figures 1 and 2 provide local polynomial plots of the relationship of tax haven investment and foreign nonhaven taxation for manufacturing and service firms with at least two foreign affiliates in the pooled sample. The $x$-axis shows the average of the statutory tax rates faced by a parent firm's foreign affiliates in nonhaven countries weighted by number of employees, which is the measure of foreign nonhaven taxation used in the empirical analysis. ${ }^{12}$ Foreign tax rates are weighted by number of employees to reflect sizes of foreign operations, and therefore potential production of taxable

12 The number of employees is adjusted by the participation of the parent in the affiliate.

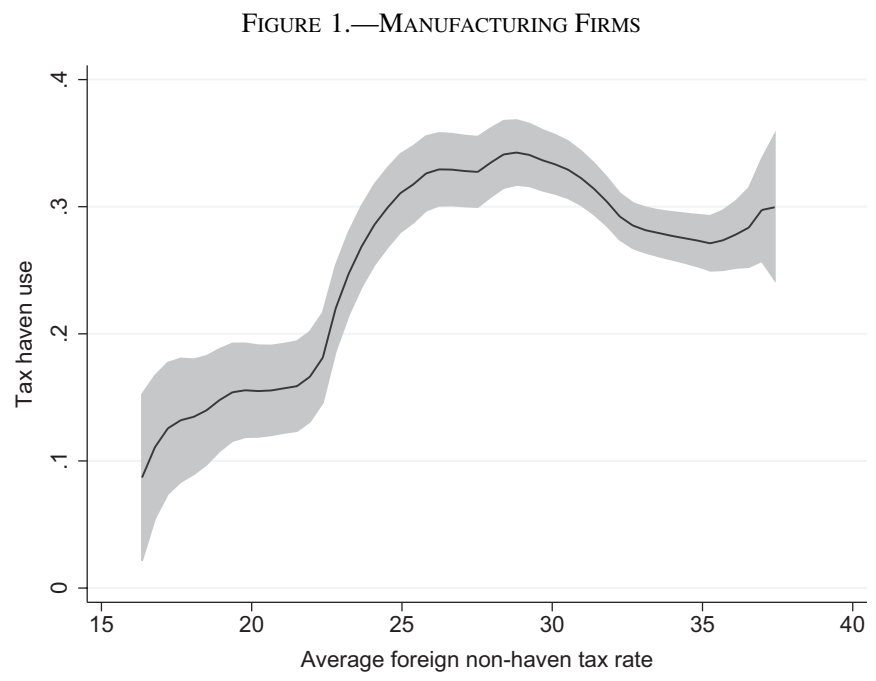

This figure displays the graph resulting from a kernel-weighted local polynomial regression of the relationship of tax haven use and the average foreign nonhaven tax rate by firms with at least two foreign affiliates for manufacturing firms. The average foreign nonhaven tax rate is measured in percent, and tax haven use is displayed as a fraction of firms; the shaded region is the $95 \%$ confidence interval. Observations in the lowest and highest percentile of the average foreign nonhaven tax rate are excluded.

FigURE 2.-SERVICE FIRMS

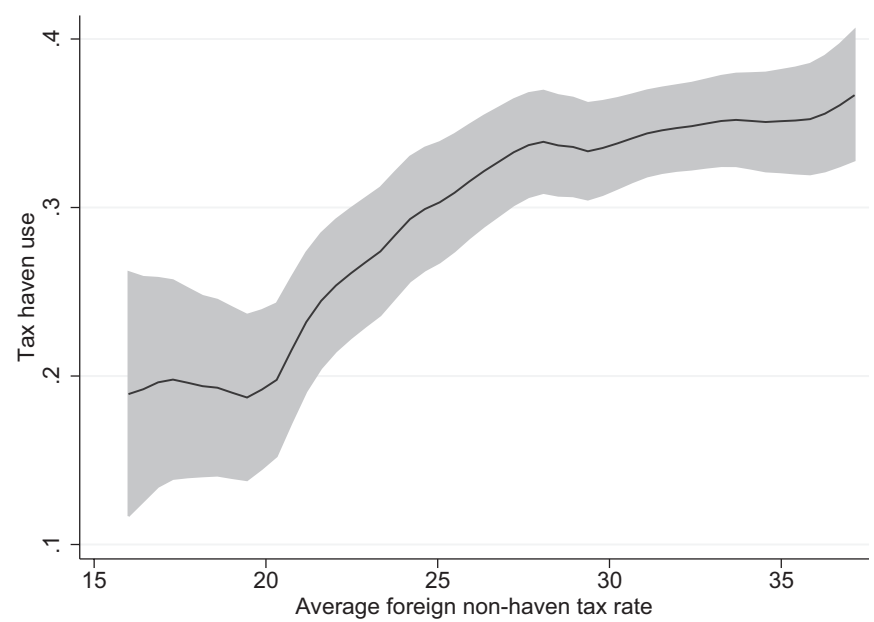

This figure displays the graph resulting from a kernel-weighted local polynomial regression of the relationship of tax haven use and the average foreign nonhaven tax rate by firms with at least two foreign affiliates for service firms. The average foreign nonhaven tax rate is measured in percent; tax haven use is displayed as fraction of firms; the shaded region is the $95 \%$ confidence interval. Observations in the lowest and highest percentile of the average foreign nonhaven tax rate are excluded.

income subject to different tax rates; weighting foreign tax rates by assets or sales produces similar results, though with smaller samples due to data limitations. The variable on the $y$-axis is tax haven use, a binary variable that is equal to 1 whenever a parent invested in at least one tax haven in a given year. For both service firms and manufacturing firms, the cross-sectional relationship of taxation and tax haven use increases over a wide range of tax rates. The increase for manufacturing firms is steeper than for service firms, though both largely level off at average foreign tax rates above $25 \%$ to $28 \% .13$

${ }^{13}$ We explored an empirical specification including a quadratic term of the foreign nonhaven tax rate, but a quadratic relationship is not robustly supported by the data. 
TABle 2.-Summary Statistics, REgRESSION SAMPLE

\begin{tabular}{|c|c|c|c|c|c|c|c|c|c|}
\hline & \multicolumn{3}{|c|}{ Full Sample } & \multicolumn{3}{|c|}{ Manufacturing Firms } & \multicolumn{3}{|c|}{ Service Firms } \\
\hline & Mean & SD & $\begin{array}{c}\text { Mean } \\
\text { Difference }\end{array}$ & Mean & SD & $\begin{array}{c}\text { Mean } \\
\text { Difference }\end{array}$ & Mean & SD & $\begin{array}{c}\text { Mean } \\
\text { Difference }\end{array}$ \\
\hline Have haven & .151 & .359 & - & .152 & .359 & - & .147 & .355 & - \\
\hline [within variation] & & .138 & - & & .135 & - & & .135 & - \\
\hline Number of parent employees (in 1,000 ) & 1.425 & 8.167 & $4.175^{* * *}$ & 1.413 & 7.189 & $4.188^{* * *}$ & 1.495 & 10.419 & $4.401^{* * *}$ \\
\hline Ln (number of parent employees) & 5.604 & 1.783 & $1.234^{* * *}$ & 6.011 & 1.380 & $1.108^{* * *}$ & 4.666 & 2.201 & $1.415^{* * *}$ \\
\hline Number of nonhaven employees (in 1,000 ) & .519 & 2.573 & $1.540^{* * *}$ & .584 & 2.959 & $1.887^{* * *}$ & .382 & 1.517 & $.776^{* * *}$ \\
\hline Ln (number of nonhaven employees) & 4.609 & 1.710 & $1.337^{* * *}$ & 4.784 & 1.642 & $1.454^{* * *}$ & 4.216 & 1.786 & $1.080^{* * *}$ \\
\hline Average foreign nonhaven tax rate & .299 & .056 & $0.005^{* * *}$ & .303 & 0.053 & $0.003^{* *}$ & .296 & 0.057 & $0.008^{* * *}$ \\
\hline Average tax rate at 2001 nonhaven locations & .315 & .058 & $0.017^{* * *}$ & .320 & 0.055 & $0.015^{* * *}$ & .307 & 0.060 & $0.017^{* * *}$ \\
\hline Average market size & 6.715 & 1.327 & $-0.082^{* *}$ & 6.858 & 1.331 & $-0.177^{* * *}$ & 6.509 & 1.276 & 0.069 \\
\hline Average distance & 7.176 & 0.998 & $0.223^{* * *}$ & 7.296 & 1.002 & $0.223^{* * *}$ & 6.932 & 0.959 & $0.237^{* * *}$ \\
\hline Average regulatory quality & 1.134 & 0.486 & $-0.032^{* *}$ & 1.112 & 0.479 & $-0.025^{* *}$ & 1.206 & 0.483 & $-0.066^{* * *}$ \\
\hline Average rule of law & 1.051 & 0.599 & -0.005 & 1.022 & 0.580 & 0.002 & 1.143 & 0.627 & $-0.048^{*}$ \\
\hline Average control of corruption & 1.059 & 0.728 & $0.037^{* *}$ & 1.023 & 0.703 & $0.051^{*}$ & 1.178 & 0.767 & -0.038 \\
\hline Observations & 12,755 & & & 8,533 & & & 3,751 & & \\
\hline
\end{tabular}

Full sample includes parent firms in the sectors agriculture, mining, electricity and water supply, and construction, in addition to manufacturing and service firms. Mean difference by haven status; base category: does not hold an affiliate in tax haven. $* p<0.10, * * p<0.05, * * * p<0.01$.

Manufacturing firms: firms classified NACE 1500-3700; service firms: firms classified NACE 5000-9300, with the already noted sample restrictions. Have haven: indicator variable; 1 if parent firm owns at least one affiliate in at least one tax haven in a given year, 0 otherwise. Number of parent employees: number of employees, parent firm. Number of nonhaven employees: sum of number of employees in affiliates not located in tax havens, reduced according to share of participating interests. Average foreign nonhaven tax rate: Average of the statutory tax rates faced by foreign affiliates in nonhaven locations weighted by affiliate number of employees, adjusted by share of participation where appropriate. Average tax rate at 2001 nonhaven locations: Average of the statutory tax rates faced by foreign affiliates in nonhaven locations of 2001 weighted by GDP. Average market size: mean GDP of foreign nonhaven countries where firms invest. Average distance: mean distance of these foreign nonhaven countries (source: CEPII). Average regulatory quality, rule of law, control of corruption: mean scores of these foreign nonhaven countries from the World Governance Indicators (WGI) for the indicators regulatory quality, rule of law, and control of corruption. The numbers of observations are 12,731, 8,518, and 3,742 for the WGI indicators because data are not available for Taiwan.

The top part of table 2 provides an overview of the main variables used in our regression analysis for the full sample and the two subgroups we consider. We explain the variables in detail in the next section. The proportion of firms investing in a tax haven is lower (around 15\%) than for the full data and equal across sectoral groups, because firms investing only in a tax haven drop from the regression sample. As firms with 0 sales or employees drop, the average size of the firms used in our regressions is slightly higher than the average size of all firms in the sample. The statistics of the average foreign nonhaven tax rate and the instruments for the regression sample are similar. ${ }^{14}$ The third columns for every group report mean difference tests of the main regressors by the dependent variable. Firms that invest in a tax haven are on average significantly larger, both domestically and internationally. In addition, they face significantly higher average foreign tax rates, which is consistent with the incentives discussed earlier.

The bottom part of table 2 compares the characteristics of foreign nonhaven investment destinations of firms with and without tax haven affiliates. Firms with tax haven affiliates appear to invest in countries that are smaller on average, though there is no significant difference in market size for service firms. They invest in countries that are more distant from Germany. Concerning the institutional quality as measured by the World Governance Indicators (WGI), their investment destinations exhibit a significantly lower regulatory quality and, for service firms, a significantly lower

\footnotetext{
14 We drop $4.1 \%$ of manufacturing firms and $8.6 \%$ of service firms because only investment in tax havens is observed. We drop $4.0 \%$ of the remaining manufacturing firms and $18.0 \%$ of service firms due to their 0 number of employees. Table C.1 in the supplementary material presents the summary statistics for the full data.
}

perception of the rule of law. The control of corruption seems to be slightly better in destination countries of firms that invest in tax havens, at least for the full sample and manufacturing firms.

\section{Empirical Approach}

As outlined in section II, a multinational firm's decision to invest in a tax haven depends on the taxation it faces at its foreign nonhaven locations, its marginal cost of reallocating taxable income, and the fixed cost of tax haven investment. Conditional on pretax foreign income, the probability of tax haven investment should increase as foreign nonhaven tax rates rise, with this effect being strongest for firms with low costs of reallocating profits.

We specify the following linear probability model:

$$
\begin{aligned}
y_{j t}= & \beta_{0}+\beta_{1} \tau_{j t}+\beta_{2} p_{j t}+\beta_{3} p_{j t}^{2}+\beta_{4} n h_{j t}+\beta_{5} n h_{j t}^{2} \\
& +\alpha_{j}+\gamma_{t}+u_{j t} .
\end{aligned}
$$

The dependent variable $y_{j t}$ is a dummy that is equal to 1 if a firm $j$ holds at least one affiliate in at least one tax haven in a year $t$. Our independent variables are $\tau_{j t}$, the average of the statutory tax rates faced by $j$ 's nonhaven affiliates in $t$ weighted by the number of affiliate employees; $p_{j t}$, the natural $\log$ of the size of company $j$ in period $t$ and its square, $p_{j t}^{2} ; n h_{j t}$, the natural log of the size of $j$ 's foreign nonhaven activities in $t$ and its square, $n h_{j t}^{2}$; $\alpha_{i}$, the firm-specific costs of reallocating profits across countries; and $\gamma_{t}$, a year fixed effect.

The coefficient of main interest is $\beta_{1}$. As indicated above, we expect $\beta_{1}>0$. It captures the effect of the taxes levied on the profits of a multinational's foreign nonhaven affiliates on the probability that it invests in a tax haven. Equation (11) 
implies that greater firm profitability increases the impact of nonhaven tax rates on the likelihood of investing in a tax haven affiliate. Thus, we use a weighted, not a simple, average of the foreign nonhaven tax rates. For this purpose, we use the number of employees of the affiliate, adjusted by the degree of participation of the parent, to approximate the relative importance of an affiliate for a multinational group. We also explore alternative weights and find that our results are largely unaffected (see supplementary table C.5).

There are two potentially important challenges in estimating equation (18): the endogeneity of the observed foreign nonhaven tax rates and unobserved firm heterogeneity in the cost of investing in a tax haven. The variable cost of advantageously using a tax haven affiliate should vary with firm-specific characteristics such as the extent to which a firm holds and uses intangible assets such as intellectual property. The location of intangible assets, license arrangements, and royalty payments have been shown to be used as income reallocation tools (e.g., Dischinger \& Riedel, 2011; Karkinsky \& Riedel, 2012). ${ }^{15}$ A firm with larger intangible assets should have greater discretion in choosing transfer prices due to the lack of comparable market transactions. Thus, and as suggested by equation (16), the response to changes in foreign taxation should vary across firms depending on their marginal cost of income reallocation. These firm-specific characteristics are, however, unobservable.

We take two measures to address this issue. First, we conduct our analysis separately for the group of manufacturing firms (NACE 1500-3700) and for the group of service firms (NACE 5000-9300, with the already noted restrictions), ${ }^{16}$ out of concern that manufacturing firms may rely to a significantly greater degree on intangible property. Furthermore, manufacturing and service firms may have differing tax and nontax determinants of foreign location and may differ in the extent to which foreign locations can substitute for each other. One observable indicator of differences between manufacturing and service firms is that manufacturing firms are more R\&D intensive. Using sector-level data from the Innovation Survey of the Center for European Economic Research (Zentrum für Europäische Wirtschaftsforschung, ZEW) for the years 1996 to 2008, we find that the average R\&D intensity for the manufacturing sector is twice as high as the $R \& D$ intensity for service sectors. At the same time, the descriptive evidence provided in section IV shows that the proportion of service firms owning tax haven affiliates and the share of service firms' affiliate years observed in tax havens are higher than the corresponding statistics for manufacturing firms. Firms in service industries have operations in tax havens in part to provide business services to other firms located there; consequently, some of the attraction may stem not from their own tax avoidance but from

\footnotetext{
15 In addition, a variant of this type of strategy is part of all six case studies of the report by the Joint Committee on Taxation (2010) prepared for the public hearing before the House Committee on Ways and Means.

16 This implies that we do not consider parent firms in agriculture, mining, electricity and water supply, and construction in our analysis.
}

that of others. Furthermore, there may be lower fixed costs of tax haven investment for service firms, so not only taxation but also parent size could have a differential impact on tax haven investment by manufacturing and service firms. In addition, the share of service affiliates of manufacturing parents located in tax havens is disproportionately higher than the share located in nonhaven countries. Overall, there is thus reason to believe that the processes governing tax haven investment by service firms and by manufacturing firms may differ significantly, which suggests that they should be analyzed separately. We report the results of a full-sample analysis in the supplementary material in table C.2.

The second way in which the analysis addresses unobserved firm heterogeneity is through the use of firm fixed effects to capture the influence of firm-specific differences in the marginal cost of income reallocation, at least to the extent that they are approximately constant over the sample period. Fixed effects also account for unobserved firm-specific characteristics such as the degree of tax sensitivity, that is, the importance that a firm assigns to the amount of its tax payments, which may render firms ex ante more or less likely to invest in tax havens. ${ }^{17}$ Likewise, the data provide information on the sector of the affiliates mostly at the two-digit NACE Rev. 1 level, so particular incentive schemes for firms in subsectors cannot be taken into account, and we do not have information on the subnational location of firms, so we cannot account for local taxation. The use of firm-fixed effects controls for time-invariant aspects of these firm attributes.

In estimating equation (18), it is necessary to take into account that the average foreign nonhaven tax rate is endogenous because entry in a tax haven may have a feedback effect on the optimal location decisions of a firm, as discussed in section III. To address this issue, we use an instrumentation strategy based on the initial location decisions of the firm. We fix the location decisions of the firm in the year 2001 , the year prior to our analysis period, and instrument the observed average foreign nonhaven tax rate with a hypothetical average foreign nonhaven tax rate had the firm not changed the locations of its foreign affiliates. The instrument thus captures only changes in firms' foreign nonhaven taxation that result from changes in tax rates, not from changes in location decisions. ${ }^{18}$ To counter any endogeneity that may be left on the intensive margin, we use GDP instead of the number of employees as weights when calculating our instrument. 19 Our instrumentation strategy thus eliminates the endogeneity in the observed average foreign nonhaven tax rate by leveraging the insights drawn from our theoretical analysis: with the endogeneity stemming from firms adjusting their nonhaven investment due to tax haven investment,

\footnotetext{
17 This issue has been raised but not addressed in Desai et al. (2006).

18 Sixty-nine of the 101 countries in the 2002 sample changed their tax rates over the 2002-2008 period. In most cases, these changes were reductions, though there is sufficient cross-sectional variation (including some tax rate increases) to identify tax rate effects.

${ }^{19}$ Earlier studies indicate that GDP correlates very closely with foreign investment and foreign profitability in both an aggregate cross section (e.g., Hines \& Rice, 1994) and a firm-level panel (e.g., Desai et al., 2006).
} 
our instrument abstracts from any changes in the average foreign nonhaven tax rate that may be induced due to firms investing or ceasing to invest in a tax haven after 2001. This instrumenting strategy requires that the distribution of foreign investment in 2001 be unrelated to subsequent changes in demand for tax haven affiliates except through the effect of changing statutory tax rates, which is entirely plausible given the unpredictability of tax changes. Tax rates generally declined over this period, though there was significant variation among countries. In an earlier version of this paper, results using an instrumentation strategy similar to Desai et al. (2006) are derived (Gumpert, Hines, \& Schnitzer, 2011).

Other considerations in estimating equation (18) include that, in principle, the probability of tax haven investment is also influenced by taxation in the multinational's home country. As we use a panel data set of German multinational firms, this effect cannot be gauged explicitly due to lack of sufficient variation. Still, changes in home country taxation are indirectly taken into account through the year fixed effect.

Other independent variables include parent size and the size of the parent's nonhaven activities, capturing the impact of size on profitability. Recent literature on foreign direct investment suggests that larger firms with bigger international activities can be expected to be more productive than their smaller competitors (Helpman, Melitz, \& Yeaple, 2004; Tomiura, 2007; Yeaple, 2009; Chen \& Moore, 2010). Consequently, these firms are better able to overcome the fixed and variable costs associated with setting up an affiliate in a tax haven and its subsequent use for income reallocation.

We use numbers of employees to measure parent size and the size of the company's foreign nonhaven activities, reduced according to the share of participation interests where applicable. Because the distribution of the size variables is strongly skewed to the right, the regressions use the natural $\log$ of employees as a size measure. Thus, observations for which the size variables are 0 drop from our regression sample. Following Desai et al. (2006), regressions include the size measures both linearly and squared.

In sum, we estimate our regression equation in four ways:

- Pooled linear probability model

- pooled linear instrumental variables model

- Linear fixed-effects model

- Linear fixed-effects model with instrumental variables

The linear fixed-effects model with instrumental variables is our preferred specification because it takes all sources of endogeneity into account, though when using it, the tax coefficients are identified only by firms that change their ownership of tax havens, which only $6.92 \%$ of the sample does. It is therefore valuable to consider the results of all four specifications, because they offer evidence of the factors that drive a firm's decision to invest in a tax haven beyond that available from only the fixed-effects IV regression. By comparing estimates of pooled and instrumental variables, it is possible to assess the bias due to endogeneity of the foreign location decisions. Juxtaposing the results of pooled and fixed-effects specifications facilitates a balanced assessment of the influence of taxation, abstracting from unobservable differences in costs of using tax haven operations.

We use a linear probability model because otherwise it would be difficult to address the endogeneity issues satisfactorily in a limited dependent-variables framework. ${ }^{20}$ Using logit or probit would yield more accurate marginal effects at different points of the distribution of the covariates, though it is reassuring that at most $7 \%$ of the predicted first-stage probabilities of investing in tax havens in the regressions reported in table 3 lie outside the $[0,1]$ interval. In the logit framework, using firm fixed-effects would be possible, but it is more problematic to use instruments. ${ }^{21}$ In the probit framework, we could conduct an instrumental variables analysis (though under very strong distributional assumptions) but would not be able to use firm fixed effects.

We generally use standard errors clustered at the level of the parent. For the fixed-effects instrumental variables regression, we use bootstrapped standard errors, as clustered standard errors cannot be estimated. As Efron and Tibshirani (1998) recommended, the bootstrap estimates are based on 200 replications.

\section{Results}

Table 3 presents the regression results. The first four columns in the table present results for the sample of manufacturing firms, and columns 5 to 8 present results for the sample of service firms. The odd-numbered columns present the results if no instrument is used, and the even-numbered columns contain the IV estimates. ${ }^{22}$ The $F$-test for exclusion of the instrument in the first-stage regression is rejected at high significance levels in all cases. The absolute value of the $F$-statistic is higher than the threshold of 10 recommended by Staiger and Stock (1997) to obtain unbiased estimates and higher than the thresholds proposed by Stock and Yogo (2002) to assume standard errors are unbiased.

The average foreign nonhaven tax rate is estimated to have a significantly positive effect on the probability of a manufacturing firm's investing in a tax haven throughout regressions. The coefficient in the 2SLS regressions is about twice as high, and significantly so, as the coefficient in the

\footnotetext{
${ }^{20}$ The results were replicated using logit, probit, fixed-effects logit, and IV probit, all of which are presented in supplementary tables C.8 and C.9. This omits a limited dependent-variable model with fixed effects and instrumental variables, which would be unidentified.

${ }^{21}$ Purely practically, one could construct an IV variant of fixed-effects logit by plugging in the predicted values from an OLS first-stage regression in place of the endogenous variable and run a fixed-effects logit second-stage regression. We refrain from doing so because this approach may not produce consistent estimates, as conditional expectations do not pass through nonlinear functions (see Wooldridge, 2002, and Angrist \& Pischke, 2009).

22 Regression results for the full sample and first-stage equations for the IV estimates, are reported in the supplementary material in tables C. 2 and C.3. The effect of the tax rate is estimated to be significantly positive in both the OLS and 2SLS specification and insignificant if fixed effects are included.
} 
TABLE 3.-REGRESSION RESULTS

\begin{tabular}{|c|c|c|c|c|c|c|c|c|}
\hline & \multicolumn{4}{|c|}{ Manufacturing } & \multicolumn{4}{|c|}{ Service } \\
\hline & OLS & 2SLS & $\mathrm{FE}$ & FEIV & OLS & 2SLS & $\mathrm{FE}$ & FEIV \\
\hline & 1 & 2 & 3 & 4 & 5 & 6 & 7 & 8 \\
\hline \multirow{2}{*}{$\begin{array}{l}\text { Average foreign } \\
\text { nonhaven tax rate }\end{array}$} & $0.615^{* * *}$ & $0.999^{* * *}$ & $0.256^{* *}$ & $0.347^{*}$ & $0.627^{* * *}$ & $1.018^{* * *}$ & -0.064 & 0.171 \\
\hline & $(0.122)$ & $(0.156)$ & $(0.113)$ & $(0.184)$ & $(0.203)$ & $(0.211)$ & (0.149) & $(0.206)$ \\
\hline \multirow[t]{2}{*}{ Parent size } & $-0.061^{* *}$ & $-0.058^{* *}$ & -0.014 & -0.014 & 0.016 & 0.016 & -0.010 & -0.010 \\
\hline & $(0.025)$ & $(0.025)$ & $(0.029)$ & $(0.027)$ & $(0.018)$ & $(0.018)$ & $(0.012)$ & $(0.014)$ \\
\hline \multirow[t]{2}{*}{ Parent size, squared } & $0.008^{* * *}$ & $0.008^{* * *}$ & 0.004 & 0.004 & 0.001 & 0.001 & 0.001 & 0.001 \\
\hline & $(0.002)$ & $(0.003)$ & $(0.003)$ & $(0.003)$ & $(0.002)$ & $(0.002)$ & $(0.002)$ & $(0.002)$ \\
\hline \multirow{2}{*}{$\begin{array}{l}\text { Foreign nonhaven } \\
\quad \text { size }\end{array}$} & $-0.051^{* * *}$ & $-0.049^{* * *}$ & $-0.045^{* * *}$ & $-0.044^{* *}$ & $-0.068^{* *}$ & $-0.065^{* *}$ & $-0.052^{* *}$ & $-0.051^{* *}$ \\
\hline & $(0.019)$ & $(0.019)$ & $(0.017)$ & $(0.017)$ & $(0.030)$ & $(0.030)$ & $(0.023)$ & $(0.026)$ \\
\hline \multirow{2}{*}{$\begin{array}{l}\text { Foreign nonhaven } \\
\text { size, squared }\end{array}$} & $0.011^{* * *}$ & $0.011^{* * *}$ & $0.008^{* * *}$ & $0.008^{* * *}$ & $0.012^{* * *}$ & $0.012^{* * *}$ & $0.010^{* * *}$ & $0.010^{* * *}$ \\
\hline & $(0.002)$ & $(0.002)$ & $(0.002)$ & $(0.002)$ & $(0.004)$ & $(0.004)$ & $(0.004)$ & $(0.004)$ \\
\hline \multirow[t]{2}{*}{ Constant } & 0.004 & -0.117 & 0.026 & 0.007 & -0.074 & $-0.176^{*}$ & $0.184^{* * *}$ & 0.118 \\
\hline & $(0.078)$ & $(0.086)$ & $(0.083)$ & $(0.087)$ & $(0.090)$ & $(0.093)$ & $(0.069)$ & $(0.077)$ \\
\hline Number of observations & 8,533 & 8,533 & 8,533 & 8,533 & 3,751 & 3,751 & 3,751 & 3,751 \\
\hline Number of parents & 1,696 & 1,696 & 1,696 & 1,696 & 832 & 832 & 832 & 832 \\
\hline$R^{2}$ overall & 0.17 & 0.17 & 0.17 & 0.17 & 0.11 & 0.10 & 0.08 & 0.09 \\
\hline$R^{2}$ within & - & - & 0.02 & 0.02 & - & - & 0.02 & 0.03 \\
\hline Year dummies & Yes & Yes & Yes & Yes & Yes & Yes & Yes & Yes \\
\hline Instrument & No & Yes & No & Yes & No & Yes & No & Yes \\
\hline$F$-statistics & - & $4,064.39^{* * *}$ & - & $465.73^{* * *}$ & - & $1,872.06^{* * *}$ & - & $717.80^{* * *}$ \\
\hline Standard errors & Cluster & Cluster & Cluster & Bootstrap & Cluster & Cluster & Cluster & Bootstrap \\
\hline
\end{tabular}

${ }^{*} p<0.10, * * p<0.05, * * * p<0.01$. Standard errors in parentheses. Standard errors are clustered at the level of the parent firm or bootstrapped with 200 replications. Regression sample: columns $1-4$ manufacturing firms (i.e., firms classified NACE 1500-3700); columns 5-8, service firms (i.e., firms classified NACE 500-9300, except NACE 65xx, 70xx, 7490, 75xx). Dependent variable: dummy variable that denotes whether a parent owns at least one affiliate in at least one tax haven in a given year. Independent variables: see table 2.

pooled OLS regression, which does not take the endogeneity of the average foreign nonhaven tax rate into account. Likewise, the coefficient in the fixed-effects IV specification is slightly higher than in the simple fixed-effects regressions, though the difference is not significant. This suggests that the true effect of the average foreign nonhaven tax rate is underestimated if the endogeneity of the observed tax rate due to simultaneity is not taken into account.

The estimates suggest that the magnitude of the tax effect is sizable when interpreted in the context of limited tax haven use by German firms. The 0.347 coefficient estimate in column 4 of table 3 implies that increasing a firm's average foreign tax rate by 1 percentage point is associated with a $0.347 \%$ greater likelihood of holding a tax haven affiliate. ${ }^{23}$ Since, according to table 2, $15.2 \%$ of German manufacturing firms in the regression sample have tax haven affiliates, the implied semielasticity of tax haven demand is $0.347 / 0.152=$ 2.3 , meaning that a 1 percentage point higher foreign nonhaven tax rate is associated with $2.3 \%$ greater demand for a tax haven affiliate. Greater domestic and foreign activities are associated with a higher likelihood of tax haven investment, and the estimated coefficients on the size variables are largely unaffected by the use of the instruments. The effect of parent size turns insignificant in specifications that include fixed effects.

As the regression results in the columns 5 to 8 of table 3 show, the estimated effect of the average foreign nonhaven tax rate on tax haven investment by service firms varies with the estimation approach. It is positive and significant

\footnotetext{
23 This and other estimated tax effects change very little if the average population of countries in which a firm has its nonhaven operations is included as an explanatory variable.
}

in the pooled OLS specification; larger and significant when estimated with 2SLS; and the point estimates of the tax coefficients in the regressions for service firms in columns 5 and 6 are almost identical to the point estimates of the tax coefficients in the corresponding regressions for manufacturing firms presented in columns 1 and 2. The tax coefficients in the fixed-effects regressions for service firms reported in columns 7 and 8 are statistically 0 .

The estimates reported in columns 5 to 8 of table 3 suggest that the probability of tax haven investment by service firms is generally unaffected by the size of parent companies. This is largely the product of the quadratic functional form imposed by these regressions (and that appear to fit well for manufacturing firms); in alternative regressions in which parent size is entered linearly, its estimated coefficient is positive and statistically significant in both the OLS and the IV specifications. Levels of foreign activity outside of tax havens are estimated to have nonlinear and significant effects on tax haven operations, similar to the effects found for manufacturing firms.

Our preferred estimates come from the fixed-effects IV specification. They show that manufacturing firms are more likely to invest in tax havens if they face higher tax rates in their foreign nonhaven locations, even if unobservable differences in the cost of income reallocation are taken into account. It is noteworthy that Desai et al. (2006) report the opposite pattern for U.S. firms, which are subject to a very different home-country taxation regime. ${ }^{24}$ In contrast, we do

\footnotetext{
24 The regressions reported in table 3 use instruments that differ from those used by Desai et al. (2006), though Gumpert et al. (2011) find that running these regressions using the instruments employed by Desai et al. (2006) produces results that differ little from those reported in table 3.
} 
not find a clear tax effect for service firms in our preferred framework. This difference may reflect a combination of factors: that service firms have higher costs of reallocating profits or exhibit lower variability in these costs. Manufacturing firms may rely to a greater average extent than service firms do on the returns to intangible property, the location of which may be more readily reallocated for tax purposes than are other forms of income, but the distribution of which is highly skewed, with some manufacturing firms earning significant fractions of their profits from intangible property and others very little. These factors would imply that foreign nonhaven tax rates should affect tax haven demand by manufacturing firms more heavily than service firms, even though service firms are at least as likely as manufacturing firms to establish tax haven operations in the first place. The 2SLS estimates appear to pick up the effect of omitted differences in the costs of income reallocation.

The evidence suggests that service firms face very different business opportunities in tax havens than do manufacturing firms, possibly in part due to the presence of other firms that demand their services and possibly due to lower fixed costs. The German antideferral provisions imply that a multinational not only needs to formally establish a company in a tax haven (often referred to as "letterbox company") but has to locate some productive activity there. Our evidence suggests that this could be more costly on net for manufacturing than for service firms.

\section{Robustness Checks}

\section{A. Sector-Level R\&D Intensity as a Proxy for the Marginal Cost of Profit Shifting}

Ownership of valuable intangible assets is widely thought to lower the cost of reallocating taxable income to low-tax jurisdictions. Many of a firm's intangible assets are unobservable to outsiders, but the R\&D intensity of a firm's industry is observable and is likely to be associated with ownership of intangibles. Empirical specifications with firm fixed effects and interactions between foreign tax rates and sectoral R\&D intensity therefore have the potential to indicate the extent to which differences in costs of income reallocation influence the effect of tax rates on demand for tax haven affiliates.

Sectoral data on R\&D intensity are provided by the Center for European Economic Research (Zentrum für Europäische Wirtschaftsforschung, ZEW) based on its annual Innovation Survey. We include the industry R\&D intensities as well as an interaction term of industry R\&D intensity and average foreign nonhaven tax rate in the pooled regressions. We refrain from doing so in the regressions with firm fixed effects because the firm fixed effects capture firm-level heterogeneity with regard to the R\&D intensity, so the firm fixed effects and the sectoral R\&D data are collinear.

We cluster the standard errors on industry level and drop firms assigned to different sectors in different years to avoid artificial variation. ${ }^{25}$ Our findings are presented in table 4. The estimates for manufacturing firms are largely unaffected by the inclusion of the R\&D intensity, which has an insignificantly negative coefficient in the OLS and 2SLS specifications in columns 1 and 3 . The interaction of $R \& D$ intensity and the average foreign nonhaven tax rate is positive and, in the 2SLS specification, significantly so. Given the same average foreign nonhaven tax rate, firms in sectors with higher R\&D intensity and thus lower costs of profit reallocation are more likely to invest in tax havens. The base effect of the sector R\&D intensity is negative. This implies that lower costs of profit reallocation do not increase tax haven investment per se, only if taxation renders profit reallocation sufficiently lucrative.

For service firms, neither the base effect nor the interaction of R\&D intensity with the tax rate is significant, and the other coefficients are largely unaffected by their inclusion. When service firms and manufacturing firms are analyzed together in the same sample, the effect of R\&D interacted with the foreign tax rate is positive and on the borderline of significance in the IV specification. Taken together, these observations are evidence in favor of the interpretation that the variance in profit-shifting cost is higher for manufacturing firms than for service firms, so the former react more strongly to differences in taxation and the marginal costs of profit shifting (see equation [17]). Service firms' tax haven investment in contrast is largely unaffected by (sectoral) differences in the marginal cost of profit shifting; together with the observation that the tax coefficient is insignificant in the fixed-effects specification, this points to opportunities to offer business services to other firms located in tax havens, possibly in addition to low fixed costs of tax haven investment.

\section{B. Additional Modifications of the Baseline Specification}

Average foreign tax rates used in the regressions reported in tables 3 and 4 equal statutory tax rates in all of the foreign countries in which a firm has affiliates, weighted by employment levels in each country. Employment is just one possible weight to use in constructing such average tax rates. Table C.5 in the supplementary material presents estimated tax rate coefficients from regressions identical to those presented in table 3, but for which different weights are used to construct average foreign tax rates. The estimated tax coefficients change very little between these specifications.

The coefficient estimates presented in tables 3 and 4 correspond to specifications in which a firm's contemporaneous demand for tax haven affiliates is unaffected by whether the firm has incurred the cost of establishing tax haven affiliates in prior years. To the extent that they influence outcomes, the impact of prior actions can be captured by including a lagged dependent variable in the equation for tax haven

\footnotetext{
25 We drop 639 manufacturing firms and 322 service firms for this reason. First-stage equations for the 2SLS specifications separately instrument for tax rates and tax rate $\times R \& D$ intensity interactions and are available in supplemental table C.4.
} 
TABLE 4.-REGRESSION RESUlts INCLUDING SECTOR R\&D INTENSITY

\begin{tabular}{|c|c|c|c|c|c|c|c|c|}
\hline & \multicolumn{4}{|c|}{ Manufacturing } & \multicolumn{4}{|c|}{ Services } \\
\hline & OLS & OLS & 2SLS & $2 \mathrm{SLS}$ & OLS & OLS & 2SLS & 2SLS \\
\hline & 1 & 2 & 3 & 4 & 5 & 6 & 7 & 8 \\
\hline \multirow{2}{*}{$\begin{array}{l}\text { Average foreign non } \\
\text { haven tax rate }\end{array}$} & $0.607^{* * *}$ & $0.435^{*}$ & $1.028^{* * *}$ & $0.564^{* *}$ & $0.451^{*}$ & $0.489^{*}$ & $0.971^{* * *}$ & $0.905^{* * *}$ \\
\hline & $(0.127)$ & $(0.240)$ & $(0.163)$ & $(0.279)$ & $(0.241)$ & $(0.285)$ & $(0.244)$ & $(0.275)$ \\
\hline \multirow[t]{2}{*}{ Parent size } & $-0.058^{* *}$ & $-0.057^{* *}$ & $-0.056^{* *}$ & $-0.053^{* *}$ & 0.010 & 0.010 & 0.010 & 0.010 \\
\hline & $(0.026)$ & $(0.026)$ & $(0.026)$ & $(0.026)$ & $(0.018)$ & $(0.018)$ & $(0.018)$ & $(0.018)$ \\
\hline \multirow[t]{2}{*}{ Parent size, squared } & $0.008^{* * *}$ & $0.008^{* * *}$ & $0.008^{* * *}$ & $0.008^{* * *}$ & 0.002 & 0.002 & 0.002 & 0.002 \\
\hline & $(0.003)$ & $(0.003)$ & $(0.003)$ & $(0.003)$ & $(0.002)$ & $(0.002)$ & $(0.002)$ & $(0.002)$ \\
\hline \multirow{2}{*}{$\begin{array}{l}\text { Foreign nonhaven } \\
\text { size }\end{array}$} & $-0.051^{* * *}$ & $-0.052^{* * *}$ & $-0.048^{* *}$ & $-0.051^{* * *}$ & $-0.087^{* * *}$ & $-0.087^{* * *}$ & $-0.082^{* * *}$ & $-0.082^{* * *}$ \\
\hline & $(0.019)$ & $(0.019)$ & $(0.019)$ & $(0.019)$ & $(0.027)$ & $(0.027)$ & $(0.028)$ & $(0.027)$ \\
\hline \multirow{2}{*}{$\begin{array}{l}\text { Foreign nonhaven } \\
\text { size, squared }\end{array}$} & $0.011^{* * *}$ & $0.011^{* * *}$ & $0.011^{* * *}$ & $0.011^{* * *}$ & $0.015^{* * *}$ & $0.015^{* * *}$ & $0.015^{* * *}$ & $0.015^{* * *}$ \\
\hline & $(0.002)$ & $(0.002)$ & $(0.002)$ & $(0.002)$ & $(0.003)$ & $(0.003)$ & $(0.003)$ & $(0.003)$ \\
\hline \multirow[t]{2}{*}{$\mathrm{R} \& \mathrm{D}$ intensity } & 0.000 & -0.012 & -0.001 & $-0.033^{*}$ & 0.010 & 0.020 & 0.008 & -0.009 \\
\hline & $(0.004)$ & $(0.017)$ & $(0.004)$ & $(0.018)$ & $(0.006)$ & $(0.033)$ & $(0.006)$ & $(0.035)$ \\
\hline \multirow{2}{*}{$\begin{array}{l}\text { Interaction tax R\&D } \\
\text { intensity }\end{array}$} & & 0.039 & & $0.107^{*}$ & & -0.033 & & 0.054 \\
\hline & & $(0.055)$ & & $(0.062)$ & & $(0.105)$ & & $(0.116)$ \\
\hline \multirow[t]{2}{*}{ Constant } & -0.011 & 0.039 & -0.140 & -0.006 & -0.041 & -0.053 & $-0.190^{*}$ & -0.169 \\
\hline & $(0.081)$ & $(0.104)$ & $(0.089)$ & $(0.107)$ & $(0.102)$ & $(0.114)$ & $(0.099)$ & $(0.107)$ \\
\hline Number of observations & 7,962 & 7,962 & 7,962 & 7,962 & 2,858 & 2,858 & 2,858 & 2,858 \\
\hline Number of sectoral groups & 23 & 23 & 23 & 23 & 14 & 14 & 14 & 14 \\
\hline$R^{2}$ & 0.17 & 0.17 & 0.17 & 0.17 & 0.16 & 0.16 & 0.16 & 0.16 \\
\hline Year dummies & Yes & Yes & Yes & Yes & Yes & Yes & Yes & Yes \\
\hline Instrument & No & No & Yes & Yes & No & No & Yes & Yes \\
\hline$F$-statistics tax & - & - & $3,121.24^{* * *}$ & $1,595.31^{* * *}$ & - & - & $1,463.28^{* * *}$ & $1,911.39^{* * *}$ \\
\hline$F$-statistics interaction & - & - & - & $3,093.64^{* * *}$ & - & - & - & $915.84^{* * *}$ \\
\hline Standard errors & Cluster & Cluster & Cluster & Cluster & Cluster & Cluster & Cluster & Cluster \\
\hline
\end{tabular}

$* p<0.10, * * p<0.05, * * * p<0.01$. Standard errors in parentheses. Standard errors are clustered at the level of parent industry. $P$-values of R\&D intensity for service firms in columns 5 to 8 are $11.9 \%, 15.2 \%$, $22.7 \%$, and $59.5 \%$. Dependent variable: Dummy variable that denotes whether a parent owns at least one affiliate in at least one tax haven in a given year. Independent variables: see table $2 . R \& D$ intensity: calculated as expenditures on innovation over total sales by sector. Interaction tax $R \& D$ intensity: interaction of sector R\&D intensity and firm-level average foreign nonhaven tax rate.

demand, though this requires appropriate instrumenting and that the sample be adjusted accordingly. Table C.6 in the supplementary material presents the results of estimating a system with lagged dependent variables, including twicelagged variables as instruments (as implied by pretests). Taken together the evidence suggests that demand for tax haven affiliates by manufacturing firms may be significantly influenced by prior tax haven activity.

Further, we reestimate our baseline equation using limited dependent-variable models as far as possible: probit, logit, IV probit, and fixed-effects logit. The sign pattern of the coefficients is largely robust. The average marginal effects of the average foreign nonhaven tax rate are similar to the marginal effects estimated using the linear probability model, except for the fixed-effects logit average marginal effect being insignificant for manufacturing firms. Thus, the findings are largely consistent with our previous results (see tables C.8 and C.9 in the supplementary material).

The supplementary material contains further robustness checks.

\section{Conclusion}

Tax haven operations can facilitate tax avoidance by multinational firms, but the evidence suggests that these opportunities are limited. Roughly $80 \%$ of German multinational firms do not have affiliates in tax havens, reflecting that the available tax savings are less than the costs of establishing the affiliates. Furthermore, even among the firms with tax haven operations, some undoubtedly choose their locations for normal business reasons unrelated to tax savings. Despite the apparently limited appeal of using tax haven operations to avoid taxes, the evidence is consistent with tax motivations of some firms, particularly those in manufacturing industries. Larger firms, and those with other foreign operations located in high-tax countries, are more likely than others to have affiliates in tax havens. Research-intensive firms that may have greater tax avoidance opportunities than others are the most likely to have tax haven operations.

The model implies that high foreign tax rates encourage tax haven investment, but that this effect is dampened by firm-specific marginal costs of income reallocation. Further, the model indicates that the relationship between nonhaven taxation and the incentive to invest in a tax haven is complex and composed of two opposite effects. Higher tax rates at the locations where a firm is already present before investing in a tax haven increase the probability of investing in a tax haven, as expected. In contrast, the opposite relationship holds for tax rates at locations that become attractive investment venues only for firms that also have tax haven investments: the attractiveness of tax havens increases as tax rates fall in these potential investment locations. This mechanism may in part explain the persistence of tax haven investment despite falling tax rates elsewhere.

There appear to be significant differences between the tax haven investment patterns of service and manufacturing firms. High foreign tax rates are associated with tax haven investments of manufacturing firms, which is consistent with tax havens being used to reallocate taxable 
income from jurisdictions in which it is taxed more heavily. At the mean, an increase in the average foreign nonhaven tax rate of 1 percentage point increases by $2.3 \%$ the likelihood that a manufacturing firm has a tax haven affiliate. This effect is robust to controlling for unobservable firmspecific differences. Tax haven investment by service firms is not significantly influenced by taxation if unobservable firm-specific characteristics are taken into account. This evidence is consistent with service firms facing high marginal costs of income reallocation and relatively little variability in these costs, which together depress the effects of foreign tax rate differences. Still, tax haven investment is relatively more common among service firms than among manufacturing firms, reflecting opportunities to sell business services to other firms operating in tax havens. This suggests that policy measures that raise the cost of income reallocation may discourage tax haven investment. At the same time, such policy measures may encourage firms to shift real activities to tax havens. Given the increasing share of service industries in Western economies, the tax-avoidance activities of service firms, and their consequences, offer a fruitful area for further research.

\section{REFERENCES}

Angrist, Joshua D., and Jörn-Steffen Pischke, Mostly Harmless Econometrics (Princeton: Princeton University Press, 2009).

Buettner, Thiess, Michael Overesch, Ulrich Schreiber, and Georg Wamser, "Taxation and Capital Structure Choice: Evidence from a Panel of German Multinationals," Economics Letters 105 (2009), 309-311.

Buettner, Thiess, and Georg Wamser, "Internal Debt and Multinational Profit Shifting: Empirical Evidence from Firm-Level Panel Data," National Tax Journal 66 (2013), 63-95.

Chen, Maggie X., and Michael O. Moore, "Location Decision of Heterogeneous Multinational Firms," Journal of International Economics 80 (2010), 188-199.

Clausing, Kimberly, "The Impact of Transfer Pricing on Intrafirm Trade" (pp. 173-194), in J. R. Hines, ed., International Taxation and Multinational Activity (Chicago: University of Chicago Press, 2001). - "Tax-Motivated Transfer Pricing and U.S. Intrafirm Trade Prices," Journal of Public Economics 87 (2003), 2207-2223.

"International Tax Avoidance and U.S. International Trade," National Tax Journal 59 (2006), 269-287.

Desai, Mihir A., C. Fritz Foley, and James R. Hines Jr., "A Multinational Perspective on Capital Structure Choice and Internal Capital Markets," Journal of Finance 59 (2004), 2451-2488.

"The Demand for Tax Haven Operations," Journal of Public Economics 90 (2006), 513-531.

"Domestic Effects of the Foreign Activities of U.S. Multinationals," American Economic Journal: Economic Policy 1 (2009), 181-203.

Dharmapala, Dhammika, and James R. Hines Jr., "Which Countries Become Tax Havens?" Journal of Public Economics 93 (2009), 1058-1068.

Dischinger, Matthias, and Nadine Riedel "Corporate Taxes and the Location of Intangible Assets within Multinational Firms," Journal of Public Economics 95 (2011), 691-707.

Drucker, Jesse, Google 2.4\% Rate Shows How \$60 Billion Lost to Tax Loopholes (October 2010), http://www.bloomberg.com/news/2010 -10-21/google-2-4-rate-shows-how-60-billion-u-s-revenue-lost-to -tax-loopholes.html.
Efron, Bradley, and Robert Tibshirani, An Introduction to the Bootstrap (London: Chapman \& Hall, 1998).

Egger, Peter, Wolfgang Eggert, Christian Keuschnigg, and Hannes Winner, "Corporate Taxation, Debt Financing and Foreign-Plant Ownership," European Economic Review 54 (2010), 96-107.

Grubert, Harry, and Joel Slemrod, "The Effect of Taxes on Investment and Income Shifting to Puerto Rico," this REVIEW 80 (1998), $365-373$.

Gumpert, Anna, James R. Hines Jr., and Monika Schnitzer, "The Use of Tax Havens in Exemption Regimes,” NBER working paper 17644 (2011).

Harris, David, Randall Morck, Joel Slemrod, and Bernard Yeung, "Income Shifting in U.S. Multinational Corporations," in A. Giovannini, R. G. Hubbard, and J. Slemrod, eds., Studies in International Taxation (Chicago: University of Chicago Press, 1993).

Helpman, Elhanan, Marc J. Melitz, and Stephen R. Yeaple, "Export versus FDI with Heterogeneous Firms," American Economic Review 94 (2004), 300-316.

Hines, James R. Jr., and Eric M. Rice, "Fiscal Paradise: Foreign Tax Havens and American Business," Quarterly Journal of Economics 109 (1994), 149-182.

Huizinga, Harry, and Luc Laeven, "International Profit Shifting within Multinationals: A Multi-Country Perspective," Journal of Public Economics 92 (2008), 1164-1182.

International Bureau of Fiscal Documentation, European Tax Handbook (Amsterdam: International Bureau of Fiscal Documentation, 20022006).

Global Corporate Tax Handbook (Amsterdam: International Bureau of Fiscal Documentation, 2007-2009).

Karkinsky, Tom, and Nadine Riedel, "Corporate Taxation and the Choice of Patent Location within Multinational Firms," Journal of International Economics 88 (2012), 176-185.

Lipponer, Alexander, Microdatabase Direct Investment: MiDi A Brief Guide (Frankfurt: Deutsche Bundesbank, 2009).

Lucas, Louise, Barney Jopson, and Vanessa Houlder, "Starbucks Ground Down," Financial Times, December 7, 2012.

OECD, "Towards Global Tax Co-operation. Progress in Identifying and Eliminating Harmful Tax Practices" (Paris: OECD, 2000).

Staiger, Douglas, and James H. Stock, "Instrumental Variables Regression with Weak Instruments," Econometrica 65 (1997), 557-586.

Stock, James H., and Motohiro Yogo, "Testing for Weak Instruments in Linear IV Regression," NBER technical working paper 284 (2002).

Tomiura, Eiichi, "Foreign Outsourcing, Exporting, and FDI: A Productivity Comparison at the Firm Level," Journal of International Economics 27 (2007), 113-127.

U.S. Congress Joint Committee on Taxation, "Present Law and Background Related to Possible Income Shifting and Transfer Pricing," U.S. House Committee on Ways and Means (July 2010).

Vicard, Vincent, "Transfer Pricing of Multinational Companies, Aggregate Trade and Investment Income," Banque de France working paper (2014).

"Wake Up and Smell the Coffee," Economist, December 15, 2012.

Wamser, Georg, "Foreign (In)direct Investment and Corporate Taxation," Canadian Journal of Economics 44 (2011), 1497-1524.

Weichenrieder, Alfons J., "Profit Shifting in the EU: Evidence from Germany," International Tax and Public Finance 16 (2009), 281-297.

Weichenrieder, Alfons J., and Jack M. Mintz, The Indirect Side of Direct Investment: Multinational Company Finance and Taxation (Cambridge, MA: MIT Press, 2010).

Wooldridge, Jeffrey D., Econometric Analysis of Cross Section and Panel Data (Cambridge, MA: MIT Press, 2002).

Yeaple, Stephen R., "Firm Heterogeneity and the Structure of U.S. Multinational Activity," Journal of International Economics 78 (2009), 206-215. 